\title{
The influence of the ACE (VD) polymorphism on systemic and renal vascular responses to angiotensins in normotensive, normoalbuminuric Type 1 diabetes mellitus
}

\author{
P. T. Luik ${ }^{1}$, K. Hoogenberg ${ }^{4}$, M. N. Kerstens ${ }^{2}$, B. J. Beusekamp ${ }^{3}$, P. E. de Jong ${ }^{1}$, R. P. F. Dullaart ${ }^{2}$, G. J. Navis \\ ${ }^{1}$ Department of Internal Medicine, Division of Nephrology, University Hospital Groningen, Groningen, The Netherlands \\ 2 Division of Endocrinology, University Hospital Groningen, Groningen, The Netherlands \\ ${ }^{3}$ Department of Dietetics, University Hospital Groningen, Groningen, The Netherlands \\ ${ }^{4}$ Department of Internal Medicine, Martini Ziekenhuis Groningen, Groningen, The Netherlands
}

\section{Abstract}

Aim/hypothesis. The renin-angiotensin-aldosterone system is important in diabetic nephropathy, with the angiotensin-converting-enzyme $D D$-genotype being a renal risk factor. The $D$-allele is associated with higher ACE concentrations, but functional consequences in diabetes mellitus are not known. To analyse these consequences, we assessed renal and systemic responsiveness to angiotensin I infusion, with the response to angiotensin II as reference.

Methods. Uncomplicated Type 1 (insulin-dependent) diabetic patients with contrasting genotypes (11 II and $11 D D)$ were studied, during low $(50 \mathrm{mmol} / 24 \mathrm{~h})$ and liberal $(200 \mathrm{mmol} / 24 \mathrm{~h})$ sodium diet, during a euglycaemic clamp. Angiotensin I was infused at 4 and $8 \mathrm{ng} \cdot \mathrm{kg}^{-1} \cdot \mathrm{min}^{-1}, 1 \mathrm{~h}$ each, followed by infusions of angiotensin II after a 2-h wash-out period.

Results. During low sodium, DD-homozygotes showed higher blood pressure sensitivity to angiotensin I (DD $21 \pm 5 \%$ vs II $15 \pm 5 \%, p<0.01)$. With liberal sodium, no differences in blood pressure were detect- ed, whereas angiotensin I induced a higher response of ERPF ( $D D 40 \pm 5 \%$ vs II $35 \pm 4 \%, p<0.05$ ) and RVR (DD $105 \pm 20 \%$ and $I I 89 \pm 16 \% p<0.05$ ) in $D D$-homozygotes. Differences were not explained by altered angiotensin II sensitivity. Multiple-linear regression analysis showed that angiotensin I induced responses of blood pressure and renal haemodynamics are higher in subjects carrying the $D D$-genotype. The magnitude of the responses was modulated by sodium intake and long-term glycaemic control.

Conclusion/interpretation. This study showed that responses of blood pressure and renal haemodynamics to angiotensin I are increased in diabetic subjects carrying the $D D$-genotype. Genotype-associated differences in ACE concentrations could, under certain circumstances, have functional consequenses in uncomplicated Type 1 diabetes mellitus. [Diabetologia (2003) 46:1131-1139]

Keywords Type 1 diabetes mellitus, ACE-genotype, renin-angiotensin system, renal haemodynamics, sodium intake.
Received: 18 December 2002 / Revised: 5 March 2003

Published online: 10 July 2003

(C) Springer-Verlag 2003

Corresponding author: G. J. Navis MD, Department of Internal Medicine, Division of Nephrology, University Hospital Groningen, Hanzeplein 1, PO Box 30.001, 9700 RB Groningen, The Netherlands

E-mail: g.j.navis@int.azg.nl

Abbreviations: RAAS, Renin-angiotensin-aldosterone system; ERPF, effective renal plasma flow; GFR, glomerular filtration rate; RVR, renal vascular resistance; FF, filtration fraction; MAP, mean arterial pressure; PRA, plasma renin activity; Ang, Angiotensin.
The RAAS plays an important role in progressive loss of renal function in diabetic and non-diabetic renal disease. The key enzyme of the RAAS, ACE, displays a genetic polymorphism, the insertion/deletion (I/D) polymorphism. The ACE (I/D) genotype has been reported to be relevant for the incidence of diabetic nephropathy, the rate of renal-function loss as well as therapy response to ACE inhibition in patients with diabetic and non-diabetic nephropathy, but data are conflicting and therefore difficult to interpret $[1,2,3,4,5,6,7]$.

The ACE $(I / D)$ genotype is a determinant of plasma ACE concentration, with the highest concentrations in 
$D D$ homozygotes, lowest in $I I$ homozygotes and in between values in heterozygotes [8]. There is evidence to suggest that renal [9] and vascular tissue ACE also relate to ACE genotype $[10,11]$. The functional significance of the increased ACE concentrations is so far unclear. In a pharmacological set-up in normal volunteers, we [12] and others [13] found evidence that increased ACE concentrations in the $D D$-homozygotes can have functional consequences, as in the $D D$ genotype infusion of pharmacological doses of AngI leads to an enhanced response of blood pressure and renal function as compared to the II genotype. This raises the possibility that the genotype-associated differences in ACE concentrations modulate RAAS-function. In diabetic patients the functional consequences of higher ACE concentration in the $D D$ genotype are not known. This question deserves specific interest because Type 1 and Type 2 diabetes as such can be associated with increased ACE concentrations [14, 15].

Therefore, we investigated the responses of blood pressure, renal haemodynamics and RAAS-hormones to AngI, with the responses to AngII as a reference. We studied subjects with Type 1 diabetes mellitus, who were normotensive and normoalbuminuric and in sufficient metabolic control. All subjects were studied on a low as well as a liberal sodium intake, because in previous studies in renal patients [7] and in healthy volunteers [12] we found an interaction between ACE genotype and sodium status.

\section{Subjects and methods}

We studied 22 diabetic patients. All participants gave their written informed consent for the study, which was approved by the local medical ethics committee. Patients were considered insulin-dependent because of ketosis-prone diabetes and an onset of disease before the age of 35 years. All had a diabetes duration of at least 2 years. Patients were selected for ACE (I/D) genotype (11 II vs $11 \mathrm{DD}$ ). Eligible subjects had normal findings on physical examination and no previous medical history of cardiovascular disease. Blood pressure had to be below (systolic/diastolic) 140/90 mmHg. Nephropathy was excluded, with serum creatinine less than $120 \mathrm{umol} / \mathrm{l}$ and no signs of microalbuminuria (urinary albumin $<30 \mathrm{mg} / 24 \mathrm{~h}$ ). Metabolic control had to be acceptable, with the inclusion criterion of $\mathrm{HbA}_{1 \mathrm{c}}$ less than $8.5 \%$ (mean $\pm \mathrm{SD}: \mathrm{HbA}_{1 \mathrm{c}} 7.3 \pm 0.5 \%$ ). Patient characteristics for both groups are shown in Table 1 .

Study design. All participants were studied on two occasions, after they had adhered to a low (50 mmol sodium/day) and a liberal (200 mmol/day) sodium diet, according to a study design similar to that in a previous study in healthy sujects [12]. The diets were applied in randomised order, after instruction by an experienced dietician. For each study day, subjects were instructed to maintain the prescribed sodium diet during the 7 days preceding the study day. Sodium restriction induces RAAS activation within 3 days, with concurrent sodium balance [16]. A period of 7 days has been shown to be sufficient for stabilisation of circulating hormones [17]. Potassium intake was standardised at $100 \mathrm{mmol} /$ day. During the diet patients were ambulant and continued their daily activities, refraining
Table 1. Clinical and laboratory characteristics during liberal (lib S, $200 \mathrm{mmol}$ sodium per day) and low (low S, $50 \mathrm{mmol}$ sodium per day) sodium intake in Type 1 diabetic patients with $I I$ and $D D$ genotype

\begin{tabular}{llll}
\hline & $I^{\mathrm{a}}$ & $D D^{\mathrm{a}}$ & $p$ value \\
\hline$n$ (men : women) & $11(7: 4)$ & $11(8: 3)$ & $\mathrm{NS}$ \\
Age (years) & $27.8 \pm 5$ & $28.6 \pm 7$ & $\mathrm{NS}$ \\
Diabetes duration (years) & $13.5 \pm 6$ & $11.0 \pm 3$ & $\mathrm{NS}$ \\
BMI (kg per m ${ }^{2}$ ) & $24.0 \pm 2.8$ & $23.9 \pm 2.3$ & $\mathrm{NS}$ \\
Body weight Lib S (kg) & $75.7 \pm 14.0$ & $79.6 \pm 10.7$ & $\mathrm{NS}$ \\
Body weight Low S (kg) & $75.4 \pm 14.2$ & $78.8 \pm 10.4$ & $\mathrm{NS}$ \\
HbA $(\%)$ & $7.3 \pm 0.5$ & $7.5 \pm 0.6$ & $\mathrm{NS}$ \\
UNaV (mmol per 24 h) & $238 \pm 74$ & $255 \pm 70$ & $\mathrm{NS}$ \\
$\quad$ Lib S & & & \\
UNaV (mmol per 24 h) & $45 \pm 15^{\mathrm{b}}$ & $35 \pm 16 \mathrm{~b}$ & $\mathrm{NS}$ \\
$\quad \mathrm{Low} S$ & & & \\
UalbV(mg per 24 h) Lib S & $5.8 \pm 3.6$ & $3.9 \pm 1.1$ & $\mathrm{NS}$ \\
UalbV(mg per 24 h) Low S & $6.4 \pm 5.4$ & $6.2 \pm 3.9$ & $\mathrm{NS}$ \\
ACE (U per 1) Lib S & $25.3 \pm 3.9$ & $45.7 \pm 13.5$ & $p<0.001$ \\
ACE (U per l) Low S & $26.4 \pm 4.2$ & $44.8 \pm 13.9$ & $p<0.001$ \\
\hline
\end{tabular}

a The mean $\pm \mathrm{SD}$ is given. ${ }^{\mathrm{b}} p<0.001 \mathrm{vs} \mathrm{Lib} \mathrm{S.}{ }^{\mathrm{c}} p<0.01 \mathrm{vs} \mathrm{Lib} \mathrm{S}$ $\mathrm{UNaV}$, urinary sodium excretion; UalbV, urinary albumin excretion

from heavy exercise. Compliance to the diet was checked 3 days before each study day by 24-h urine collections to ensure inclusion only when dietary compliance was good. In addition, 24-h urine was collected the last day before each study day (Table 1). Female participants were tested in the mid-luteal phase of their menstrual cycle.

After an overnight fast and having refrained from alcohol and caffeine-containing drinks for $12 \mathrm{~h}$, the participants reported at the research unit at 8:00 am. Intravenous catheters were inserted into each forearm for infusion and drawing of blood samples. During the whole study, the participants remained in a semirecumbent position in a quiet room. Patients received a low insulin infusion $\left(30 \mathrm{mU} \cdot \mathrm{kg}^{-1} \cdot \mathrm{h}^{-1}\right)$ and blood glucose was kept at $5 \mathrm{mmol} / \mathrm{l}$ by varying the infusion rate of a glucose infusion (dextrose $20 \%$ to which $20 \mathrm{ml} / 1 \mathrm{KCl}$ was added to prevent hypokalaemia), in order to minimize the effects of variations in glycaemia on systemic and renal haemodynamics $[18,19]$. To this purpose blood glucose was measured every $10 \mathrm{~min}$ on an APEC glucose analyser (APEC Inc, Danvers, Mass., USA). With this regimen, peripheral insulin concentrations are stable at approximately $30 \mathrm{mU} / 1$ [20]. Each study day, sodium intake was adjusted according to the prescribed sodium diet. The first 2 hours (from 8-10 am) served for equilibration of the renal-function tracer, and for stabilisation of blood glucose concentrations.

Blood pressure. BP was measured with a semi-automated device (Dinamap 1846, Critikon, Tampa, Fla., USA) at 15-min intervals, except during the angiotensin infusions when blood pressure was recorded every $5 \mathrm{~min}$. MAP was calculated as diastolic blood pressure plus one-third of the pulse pressure $(\mathrm{mmHg})$.

Renal function measurements. Glomerular filtration rate and effective renal plasma flow (ERPF) were measured by constant infusion of radiolabelled tracers, ${ }^{125} \mathrm{I}$-iothalamate and ${ }^{131} \mathrm{I}$-hippurate, respectively [21]. After drawing a blank blood sample, a priming solution containing $0.4 \mathrm{ml} / \mathrm{kg}$ body weight of the infusion solution $\left(0.04 \mathrm{MBq}\right.$ of ${ }^{125} \mathrm{I}$-iothalamate and $0.03 \mathrm{MBq}$ of ${ }^{131} \mathrm{I}$-hippurate) plus an extra of $0.6 \mathrm{MBq}$ of ${ }^{125} \mathrm{I}$-iothalamate was given at 8:00 am, followed by infusion at $12 \mathrm{ml} / \mathrm{h}$. To attain sta- 
ble plasma concentrations of both tracers, a 2-h stabilisation period followed, after which baseline measurements started at 10:00 am. The clearances were calculated as $\left(\mathrm{U}^{*} \mathrm{~V}\right) / \mathrm{P}$ and $\left(I^{*} \mathrm{~V}\right) / \mathrm{P}$, respectively. $\mathrm{U}^{*} \mathrm{~V}$ represents the urinary excretion of the tracer, $\mathrm{I}^{*} \mathrm{~V}$ represents the infusion rate of the tracer; $\mathrm{P}$ represents the tracer value in plasma at the end of each clearance period. This method corrects for incomplete bladder emptying and dead space, by multiplying the urinary clearance of ${ }^{125}$ I-iothalamate with the ratio of the plasma and urinary clearance of ${ }^{131} \mathrm{I}-$ hippuran [21]. The FF was calculated as the ratio of GFR and ERPF and expressed as a percentage. RVR was calculated as MAP divided by ERPF. GFR and ERPF were corrected for $1.73 \mathrm{~m}^{2}$ of body surface area. This method has a day-to-day variation coefficient of $2.5 \%$ for GFR and $5 \%$ for ERPF [21].

Angiotensin infusions. Baseline values for BP and renal haemodynamics were obtained from 10:00 to 12:00 am. From 12:00 am to 02:00 pm, Ang I (Clinalfa AG, Switzerand) was administered in the left antecubital vein in a dose of $4 \mathrm{ng} \cdot \mathrm{kg}^{-1} \cdot \mathrm{h}^{-1}$ in the first hour and $8 \mathrm{ng} \cdot \mathrm{kg}^{-1} \cdot \mathrm{h}^{-1}$ in the second hour. After a washout period from 02:00 pm to 04:00 pm, Ang II (Clinalfa AG, Switzerland) was administered from 04:00 $\mathrm{pm}$ to $06: 00 \mathrm{pm}$ in a dose of $4 \mathrm{ng} \cdot \mathrm{kg}^{-1} \cdot \mathrm{h}^{-1}$ in the first hour and $8 \mathrm{ng} \cdot \mathrm{kg}^{-1} \cdot \mathrm{h}^{-1}$ in the second hour.

Laboratory measurements. Venous blood samples were taken at the end of each clearance period. Blood was drawn from an intravenous catheter inserted into the right antecubital vein. Blood samples were immediately centrifuged at $4^{\circ} \mathrm{C}$ and the samples were stored at $-20^{\circ} \mathrm{C}$ before assay. Serum ACE activity was measured with an HPLC-assisted assay, as the generation of Hip from the substrate Hip-His-Leu. Normal values in our laboratory range from 10 to $40 \mathrm{U} / 1$ [22]. PRA was measured with a commercially available double-antibody RIA (Nichols Institute Diagnostics, San Juan Capistrano, Calif., USA). $\mathrm{HbA}_{1 \mathrm{c}}$ was measured by HPLC (Bio-Rad, Veenendaal, The Netherlands; normal range 4.6 to $6.1 \%$ ).

Statistical analysis and calculations. Data are given as means $\pm \mathrm{SD}$. The average of the BP values measured from 10 to 12.00 am (at 15-min intervals) were used as baseline BP values. The percent change in MAP during a given infusion step of AngI was analysed as the average of all MAP values measured during the 1-h infusion period (at 5-min intervals). The average of the BP values measured from 3:00 to 4:00 pm (at 15-min intervals) were used as recovery values, to which the $\mathrm{BP}$ responses to AngII infusion (at 5-min intervals during both infusion steps) were related for calculation of percent changes. The variation in the sequential bloodpressures was below 5\% for each different time interval during the study day. For renal haemodynamics, the average values of the 2-h baseline clearance period (10-12 am) were used as baseline values.

Differences between absolute mean values obtained during baseline and during the different infusion steps within each group were compared using one-way ANOVA, with post hoc Bonferroni adjustment for multiple comparisons. The AngI infusions were compared with baseline, while the AngII infusions were compared with baseline and recovery. Between genotype-group differences were tested using Student's $t$ tests for unpaired variables. The liberal and low-sodium data within each group were compared using paired samples Student's $t$ tests. Bivariate correlations were estimated by Pearson correlation coefficients. Multivariate regression analysis was conducted using linear regression models to analyse the systemic and renal responses to infusion of AngI for effects of possible confounders. Independent variables tested were ACE-genotype, sodium status (categorical variables), $\mathrm{HbA}_{1 \mathrm{c}}$ and AngII sensitivity (as the percentage increase to infusion of AngII in the same person). Two-sided $p$-values less than 0.05 were considered to be stastistically significant.

Power analysis, based on recent data in healthy subjects [12], showed that nine patients in each contrasting genotype group were required to detect an $80 \%$ difference in BPresponse with a two-sided $\alpha$ of 0.05 and a power of $80 \%$.

\section{Results}

The groups were not different with respect to diabetes duration, BMI and sex distribution. Body weight was slightly higher on liberal sodium intake. Metabolic control was - by selection-adequate in both groups (Table 1). Compliance to the low as well as the liberal sodium diet was satisfactory in both groups. As expected, plasma ACE concentrations were higher in the $D D$ group and were not modified by sodium intake.

During sodium restriction, there were numerical differences between the genotype groups in baseline ERPF and RVR that did not reach statistical significance (Table 2). Infusion of AngI caused significant dose-dependent increases in MAP, RVR and aldosterone and decreases in GFR, ERPF and PRA, with almost complete recovery during the 2 -h wash-out (Table 2). The percentage change from baseline for MAP
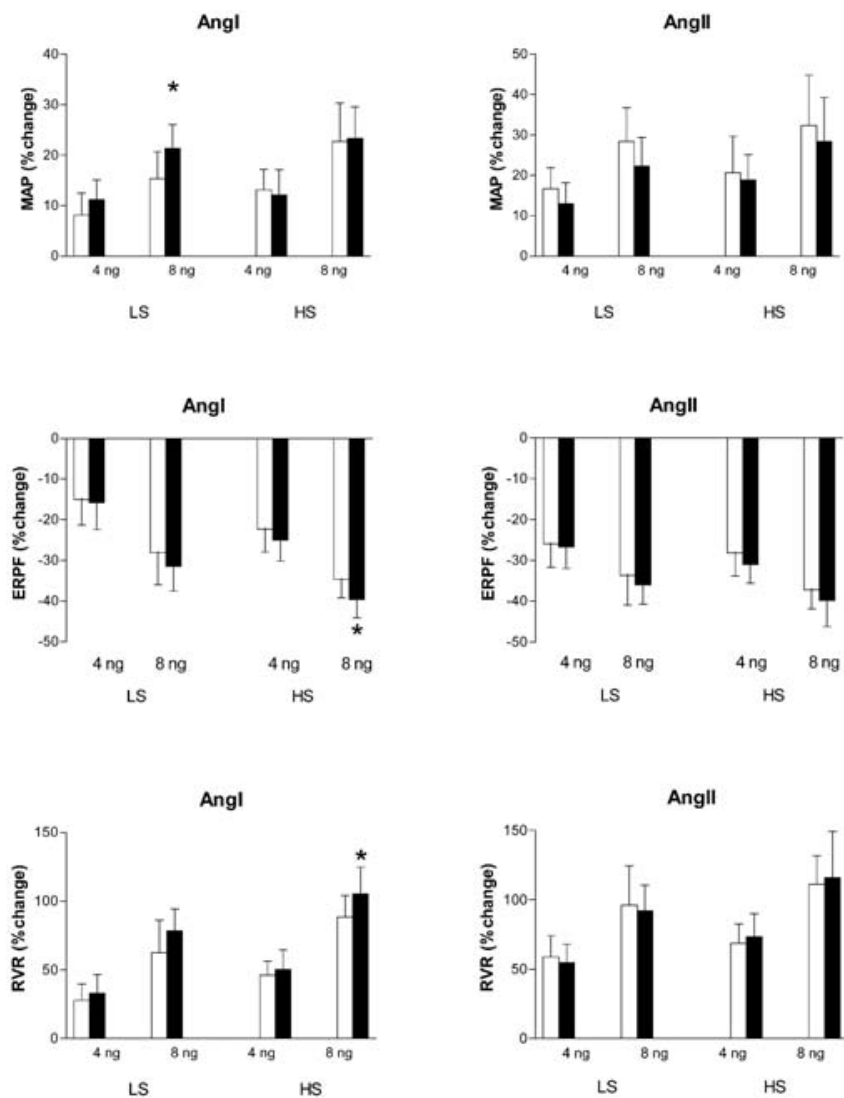

Fig. 1. Mean arterial pressure (MAP), effective renal plasma flow (ERPF) and renal vascular resistance (RVR) responses (mean \pm SD) to infusions of AngI and AngII (4 and $8 \mathrm{ng} \cdot \mathrm{kg}^{-1}$. $\left.\min ^{-1}\right)$, in subjects with the II ( $\square$ ) and DD ( $\square$ ) genotype, with a low and liberal sodium intake. ${ }^{*} p<0.05, D D$ vs $I I$ genotype 
Table 2. Baseline characteristics and responses during Ang I infusion, during recovery and during subsequent Ang II infusion, on a low sodium diet ${ }^{\mathrm{a}}$

$\begin{array}{llllll}\text { Baseline } & \text { AngI } & \text { AngI } & \text { Recovery } & \text { Ang II } & \text { Ang II } \\ & 4 \mathrm{ng} \cdot \mathrm{kg}^{-1} & 8 \mathrm{ng} \cdot \mathrm{kg}^{-1} & \text { after } 2 \mathrm{~h} & 4 \mathrm{ng} \cdot \mathrm{kg}^{-1} & 8 \mathrm{ng} \cdot \mathrm{kg}^{-1} \\ & \cdot \mathrm{min}^{-1} & \cdot \mathrm{min}^{-1} & & \cdot \mathrm{min}^{-1} & \cdot \mathrm{min}^{-1}\end{array}$

\section{II}

\begin{tabular}{|c|c|c|c|c|c|c|}
\hline MAP (mmHg) & $90 \pm 9$ & $97 \pm 11$ & $104 \pm 11^{\mathrm{c}}$ & $87 \pm 10$ & $102 \pm 12^{d}$ & $112 \pm 12^{\mathrm{bd}}$ \\
\hline $\operatorname{GFR}\left(\mathrm{ml} \cdot \mathrm{min}^{-1} \cdot 1.73 \mathrm{~m}^{-2}\right)$ & $119 \pm 17$ & $111 \pm 13$ & $111 \pm 12$ & $119 \pm 14$ & $107 \pm 14$ & $110 \pm 14$ \\
\hline RVR (MAP/ERPF) & $0.19 \pm 0.03$ & $0.24 \pm 0.04^{c}$ & $0.31 \pm 0.05^{b}$ & $0.19 \pm 0.03$ & $0.30 \pm 0.05^{\mathrm{bd}}$ & $0.37 \pm 0.08^{b d}$ \\
\hline Aldosterone $\left(\mathrm{nmol} \cdot \mathrm{l}^{-1}\right)$ & $0.26 \pm 0.1$ & $0.91 \pm 0.3^{\mathrm{b}}$ & $1.18 \pm 0.4^{b}$ & $0.20 \pm 0.1$ & $1.02 \pm 0.4^{\mathrm{bd}}$ & $1.50 \pm 0.9^{\mathrm{bd}}$ \\
\hline \multicolumn{7}{|l|}{$D D$} \\
\hline $\operatorname{ERPF}\left(\mathrm{ml} \cdot \mathrm{min}^{-1} \cdot 1.73 \mathrm{~m}^{-2}\right)$ & $508 \pm 54$ & $427 \pm 54^{c}$ & $349 \pm 8^{c}$ & $473 \pm 56$ & $347 \pm 51^{\text {bd }}$ & $303 \pm 45^{\text {bd }}$ \\
\hline RVR (MAP/ERPF) & $0.17 \pm 0.02$ & $0.23 \pm 0.04^{b}$ & $0.30 \pm 0.05^{b}$ & $0.19 \pm 0.03$ & $0.30 \pm 0.05^{\mathrm{bd}}$ & $0.37 \pm 0.06^{b d}$ \\
\hline PRA (nmol $\cdot 1^{-1}$ AngI per $\left.h\right)$ & $0.58 \pm 0.3$ & $0.36 \pm 0.2$ & $0.21 \pm 0.1^{b}$ & $0.42 \pm 0.1$ & $0.22 \pm 0.1^{\text {be }}$ & $0.16 \pm 0.1^{\text {bd }}$ \\
\hline Aldosterone (nmol.1-1) & $0.27 \pm 0.2$ & $0.97 \pm 0.7$ & $1.36 \pm 0.9^{c}$ & $0.29 \pm 0.1$ & $1.25 \pm 1.0^{\mathrm{ce}}$ & $1.58 \pm 1.1^{b d}$ \\
\hline
\end{tabular}

a The mean $\pm \mathrm{SD}$ is given, ${ }^{\mathrm{b}} p \leq 0.01$ vs baseline, ${ }^{\mathrm{c}} p \leq 0.05$ vs baseline, ${ }^{\mathrm{d}} p \leq 0.01$ vs recovery, ${ }^{\mathrm{e}} p \leq 0.05$ vs recovery

MAP, Mean arterial pressure; GFR, glomerular filtration rate;

plasma renin activity. For AngII responses, the recovery values are taken as baseline

$\mathrm{FF}$, filtration fraction; RVR, renal vascular resistance; PRA,

Table 3. Baseline characteristics and responses during Ang I infusion, during recovery and during subsequent Ang II infusion, on a liberal sodium diet ${ }^{\mathrm{a}}$

\begin{tabular}{|c|c|c|c|c|c|c|}
\hline & Baseline & $\begin{array}{l}\text { Ang I } \\
4 \mathrm{ng} \cdot \mathrm{kg}^{-1} \\
\cdot \mathrm{min}^{-1}\end{array}$ & $\begin{array}{l}\text { Ang I } \\
8 \mathrm{ng} \cdot \mathrm{kg}^{-1} \\
\cdot \mathrm{min}^{-1}\end{array}$ & $\begin{array}{l}\text { Recovery } \\
\text { after } 2 \text { h }\end{array}$ & $\begin{array}{l}\text { Ang II } \\
4 \mathrm{ng} \cdot \mathrm{kg}^{-1} \\
\cdot \min ^{-1}\end{array}$ & $\begin{array}{l}\text { Ang II } \\
8 \mathrm{ng} \cdot \mathrm{kg}^{-1} \\
\cdot \mathrm{min}^{-1}\end{array}$ \\
\hline MAP $(\mathrm{mmHg})$ & $92 \pm 10$ & $104 \pm 10^{f}$ & $112 \pm 11^{b f}$ & $91 \pm 11$ & $109 \pm 11$ bdf & $120 \pm 11^{b d f}$ \\
\hline $\operatorname{GFR}\left(\mathrm{ml} \cdot \mathrm{min}^{-1} \cdot 1.73 \mathrm{~m}^{-2}\right)$ & $122 \pm 9$ & $115 \pm 11$ & $111 \pm 12$ & $116 \pm 12$ & $106 \pm 10^{c}$ & $109 \pm 14$ \\
\hline PRA (nmol.1-1 AngI per $h$ ) & $0.22 \pm 0.2^{\mathrm{f}}$ & $0.17 \pm 0.1^{\mathrm{f}}$ & $0.16 \pm 0.1$ & $0.21 \pm 0.2^{\mathrm{f}}$ & $0.16 \pm 0.1$ & $0.14 \pm 0.1$ \\
\hline Aldosterone $\left(\mathrm{nmol} \cdot \mathrm{l}^{-1}\right)$ & $0.09 \pm 0.1^{\mathrm{f}}$ & $0.29 \pm 0.2^{\mathrm{cf}}$ & $0.41 \pm 0.2^{\mathrm{bf}}$ & $0.10 \pm 0.04^{\mathrm{f}}$ & $0.46 \pm 0.3^{\mathrm{bdf}}$ & $0.61 \pm 0.3^{\text {bdf }}$ \\
\hline \multicolumn{7}{|l|}{$D D$} \\
\hline MAP $(\mathrm{mmHg})$ & $89 \pm 6$ & $99 \pm 7^{b f}$ & $109 \pm 7^{b f}$ & $90 \pm 9$ & $107 \pm 8^{\text {bdf }}$ & $115 \pm 9^{\text {bdf }}$ \\
\hline $\mathrm{GFR}\left(\mathrm{ml} \cdot \mathrm{min}^{-1} \cdot 1.73 \mathrm{~m}^{-2}\right)$ & $125 \pm 10^{f}$ & $118 \pm 16$ & $112 \pm 11^{\mathrm{f}}$ & $124 \pm 14^{\mathrm{f}}$ & $108 \pm 13^{\text {ce }}$ & $112 \pm 11$ \\
\hline
\end{tabular}

aThe mean $\pm \mathrm{SD}$ is given, ${ }^{\mathrm{b}} p \leq 0.01$ vs baseline, ${ }^{\mathrm{c}} p \leq 0.05 \mathrm{vs}$ baseline, ${ }^{\mathrm{d}} p \leq 0.01$ vs recovery, ${ }^{\mathrm{e}} p \leq 0.05$ vs recovery, ${ }^{\mathrm{f}} p \leq 0.05$ vs low sodium, ${ }^{\mathrm{g}} p \leq 0.05$ DD vs II. MAP, Mean arterial pressure;

and renal haemodynamics after AngI infusion are shown (Fig. 1). On univariate analysis the blood pressure response to AngI was more pronounced in the $D D$ subjects than in II subjects (DD: $21 \pm 5 \%$ vs $I I$ : $15 \pm 5 \%$ on $\left.8 \mathrm{ng} \cdot \mathrm{kg}^{-1} \cdot \mathrm{min}^{-1} p<0.05\right)$. This difference was not explained by an enhanced responsiveness to AngII (DD: $22 \pm 7 \%$ vs II: $28 \pm 9$ on $8 \mathrm{ng} \cdot \mathrm{kg}^{-1} \cdot \mathrm{min}^{-1}$, NS). On univariate analysis, no differences in ERPF responses to AngI were detected during the low sodi-
GFR, glomerular filtration rate; FF, filtration fraction; RVR, renal vascular resistance; PRA, plasma renin activity. For AngII responses, the recovery values are taken as baseline

um diet, whereas RVR response tended to be more pronounced in $D D$ subjects $(D D: 78 \pm 16 \%$ vs $I I$ : $63 \pm 23 \%$ on $\left.8 \mathrm{ng} \cdot \mathrm{kg}^{-1} \cdot \mathrm{min}^{-1}, p<0.08\right)$.

During liberal sodium no differences in the increase in MAP were found. Baseline ERPF was somewhat higher, and RVR somewhat lower in the $D D$ genotype (ERPF: 568 vs $506 \mathrm{ml} \cdot \mathrm{min}^{-1} \cdot 1.73 \mathrm{~m}^{-2}$, $p<0.05$; RVR 0.16 vs $0.18 \mathrm{mmHg} \cdot \mathrm{ml}^{-1} \cdot \mathrm{min}^{-1}, p<0.05$, Table 3) than II homozygotes. Other baseline parame- 
Table 4. Multivariate regression analysis of AngI sensitivity

\begin{tabular}{|c|c|c|c|c|}
\hline Dependent variable & Determinant & Model $\mathrm{r}^{2} /$ sign. & Partial correlation & $p$ value \\
\hline \multicolumn{5}{|l|}{ MAP } \\
\hline $8 \mathrm{ng} \cdot \mathrm{kg}^{-1} \cdot \mathrm{min}^{-1}$ & $\begin{array}{l}\text { Sodium } \\
\text { ACE-genotype } \\
\text { AngII-sensitivity }\end{array}$ & $0.3334 / 0.001$ & $\begin{array}{l}0.211 \\
0.353 \\
0.437\end{array}$ & $\begin{array}{l}0.097 \\
0.007 \\
0.001\end{array}$ \\
\hline \multicolumn{5}{|l|}{ ERPF } \\
\hline \multicolumn{5}{|l|}{ RVR } \\
\hline $8 \mathrm{ng} \cdot \mathrm{kg}^{-1} \cdot \mathrm{min}^{-1}$ & $\begin{array}{l}\text { Sodium } \\
\text { ACE-genotype } \\
\text { AngII-sensitivity }\end{array}$ & $0.701 / 0.000$ & $\begin{array}{l}0.515 \\
0.541 \\
0.719\end{array}$ & $\begin{array}{l}0.001 \\
0.001 \\
0.001\end{array}$ \\
\hline
\end{tabular}

Sodium intake (low sodium 1, liberal sodium 2) and ACE-genotype (II-genotype 1, DD-genpotype 2) were included as categorial variables in the models.
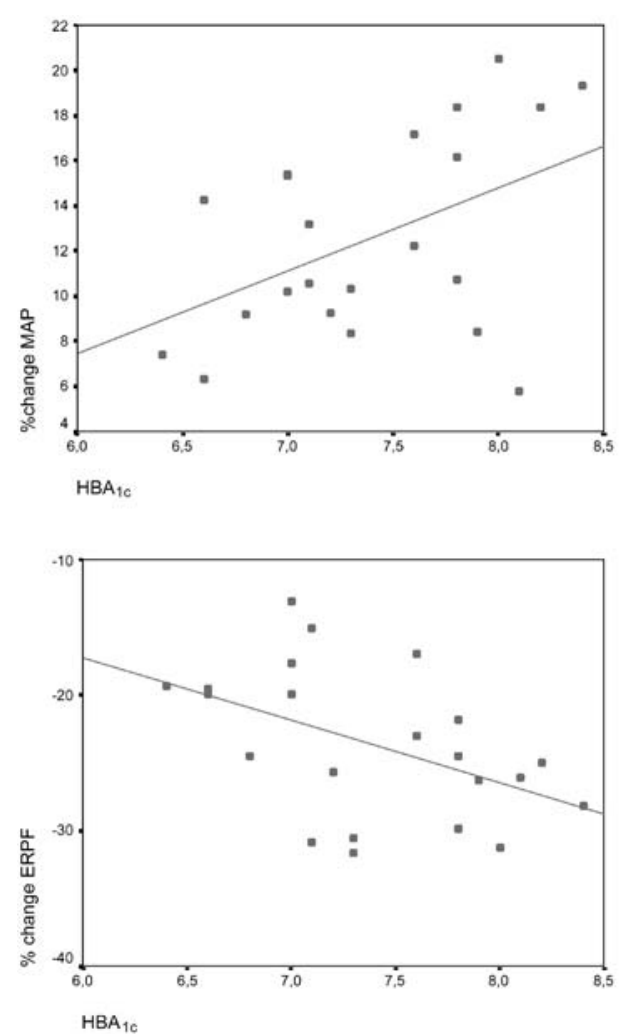

Fig. 2. Percent changes in mean arterial pressure (MAP), effective renal plasma flow (ERPF) and renal vascular resistance (RVR) to infusions of $4 \mathrm{ng} \cdot \mathrm{kg}^{-1} \cdot \mathrm{min}^{-1}$ of AngI vs $\mathrm{HbA}_{1 \mathrm{c}}$ during liberal sodium intake in all studied patients. Pearson's correlation coefficients: MAP $0.47 \quad(p<0.05), \quad$ ERPF-0.47 $(p<0.05)$, RVR $0.62(p<0.01)$

ters were similar for the genotype groups. AngI elicited the expected dose-dependent increase in MAP, RVR and aldosterone, with decreases in ERPF, GFR and PRA. The percentage change from baseline (AngI) and recovery (AngII) are shown (Fig. 1). On univari-

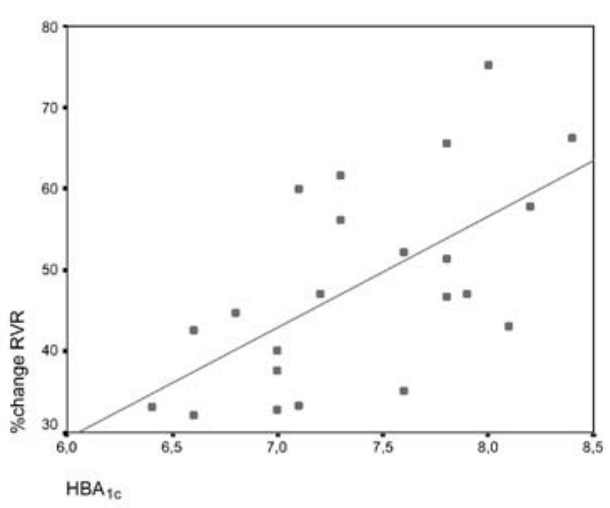

ate analysis the decrease in ERPF was more pronounced in $D D$ subjects than in $I I$ subjects $(D D$ : $-40 \pm 5 \%$ vs $I I:-35 \pm 4 \%, p<0.05)$. Accordingly, the rise in RVR was more pronounced in $D D$ subjects $(D D$ : $105 \pm 20 \%$ vs $I I: 89 \pm 16 \%, p<0.05)$. These differences in AngI response were not explained by differences in AngII response (ERPF: DD: $-36 \pm 5 \%$ vs II: $-34 \pm 7 \%$, NS; RVR: $D D: 116 \pm 33 \%$ vs II: $111 \pm 20 \%$, NS).

Multivariate regression analysis was done to test whether differences in AngI response between the genotypes might be influenced by sodium intake and glycaemic control as possible confounders, with AngII response as a covariate. Significant multivariate models were obtained for the responses of MAP, ERPF and RVR (Table 4). As anticipated, AngII response was included in all models. ACE genotype was included as an independent determinant in the models for MAP, ERPF and RVR, albeit with a partial correlation coefficient of only borderline significance for the ERPF model. The contribution of $\mathrm{HbA}_{1 \mathrm{c}}$ disappeared by inclusion of AngII responsiveness in the model, indicating that $\mathrm{HbA}_{1 \mathrm{c}}$ had an effect on AngI response, but that this effect was due to an effect on AngII responsiveness, with a larger response in subjects with 
higher $\mathrm{HbA}_{1 \mathrm{c}}$. The univariate relationships between $\mathrm{HbA}_{1 \mathrm{c}}$ and the response of MAP, ERPF and RVR to infusion of AngI are shown in Fig. 2 for the liberal sodium condition, and demonstrate a positive correlation between $\mathrm{HbA}_{1 \mathrm{c}}$ and a more pronounced reponse to AngI. During low sodium, similar trends were observed which did not reach statistical significance $\left(\mathrm{HbA}_{1 \mathrm{c}}\right.$ and MAP $r=0.37, \mathrm{NS} ; \mathrm{HbA}_{1 \mathrm{c}}$ and ERPF $r=-0.42$, NS; $\mathrm{HbA}_{1 \mathrm{c}}$ and RVR $r=0.19$, NS; data not shown).

\section{Discussion}

This study provides the first data on the responses of blood pressure and renal haemodynamics to Ang I and Ang II in patients with uncomplicated Type 1 diabetes mellitus, with contrasting ACE (I/D) genotypes. As anticipated, the magnitude of the responses to AngI and AngII was modulated by sodium intake. Moreover, the pressor responses were modified by prevalent glycaemic control. By multivariate analysis accounting for these modifying factors, we were able to show that the responses of blood pressure and renal haemodynamics to a pharmacological dosis of AngI are more pronounced in subjects with the ACE $D D$ genotype than in II genotype, which could not be explained by enhanced sensitivity to AngII in the $D D$ genotype. These data suggest that genotype-associated differences in ACE concentrations might, at least under certain circumstances, have functional consequences for RAAS-mediated responses.

Increased conversion of AngI to AngII, secondary to the higher ACE concentrations, has been suggested to be a mechanism underlying differences in cardiovascular and renal prognosis in subjects with $D D$ genotype, compared to $I$-allele carriers. Several studies in non-diabetic subjects tested this hypothesis by investigating whether enhanced responses to exogenous AngI are present in $D D$ genotype [12, 13, 23, 24]. Data, however, are conflicting $[13,24]$. Interaction with the level of background RAAS-activity could be involved in the discrepancies, as suggested by data during pre-treatment with renin-blockade [24], and by the effect of sodium intake [12]. In the latter study, our group has found that the effect of ACE genotype on AngI responses was not limited to blood pressure response, but also applied to renal haemodynamics. In the healthy subjects, sodium restriction was able to ameliorate the observed differences. Our present study applied such a design in Type 1 diabetic subjects and shows that the gene-environment interaction for the ACE-gene polymorphism is even more complex, as not only sodium status but also glycaemic control (as reflected by the $\mathrm{HbA}_{1 \mathrm{c}}$ value) seems to be a relevant contributor to the eventual phenotype.

Considering previous evidence, we took into account the effects of possible gene-environment interaction. Therefore we assessed the interaction with so- dium status on two different sodium intakes. Our data show that the magnitude of the AngI and AngII responses was larger during liberal sodium intake as an independent variable in the multiple regression analysis. This is in accord with similar findings in normal subjects, and has been attributed to up-regulation of the sensitivity of AngII receptors during high sodium intake $[25,26,27]$. On multivariate analysis we found that sodium intake also modified the effect of ACE genotype on AngI response, independent from AngII response. The mechanism underlying this interaction between sodium status, ACE genotype and AngI responsiveness may be related to effects of sodium status on tissue AngI conversion [28]. However, genotype-associated effects of differences in baseline values during the different sodium intakes might also be involved. During both sodium intakes, preinfusion renal haemodynamics were different for the contrasting genotypes with a higher ERPF with a lower RVR in $D D$ homozygotes. The difference, however, only reached statistical significance during liberal sodium intake. These differences in baseline renal vasomotor tone imply that the more pronounced net response of ERPF to AngI in $D D$-subjects should be interpreted with caution. It cannot be ascertained from our data whether the larger net response of ERPF and RVR in $D D$-subjects is due to a higher vasoconstrictive responsiveness to AngI as such, or to differences in preinfusion renal vascular tone.

The difference in pre-infusion renal haemodynamics during liberal sodium consumption (i.e. a sodium intake that is more or less ubiquitous in western societies) seems to be at variance with data from the literature. In a previous study in young, uncomplicated Type 1 diabetes mellitus, renal haemodynamics were related to the ACE-genotype, with the II-carriers having a higher GFR and ERPF [29]. These differences were attributed to augmented intrarenal AngII activity in the $D D$ genotype, resulting in a lower GFR and ERPF. This is in accordance with a study using duplex Doppler sonography reporting an increased resistance index of renal arcuate arteries in young patients with uncomplicated diabetes carrying the $D D$-genotype [30]. Our baseline data suggest the opposite. We found a state of more vasodilation in the $D D$-genotype, especially during liberal sodium intake. This might point towards a propensity to develop glomerular hyperfiltration in the $D D$-genotype-a harbinger of the development of diabetic nephropathy [31, 32]. There are, however, important differences between our study population and those from the above, which could explain these seeming discrepancies. Our patients had an average duration of 12.3 years, compared with 3.4 and 6.5 years, respectively, in the above studies. Furthermore, glycaemic control, as judged by the $\mathrm{HbA}_{1 \mathrm{c}}$ value, was better in the present study.

The diabetic subjects were tested using euglycaemic clamp, with low-dose insulin infusion, to 
avoid disturbing effects of short-term fluctuations in glucose concentrations. Glycaemic control modifies RAAS-activity, as acute hyperglycaemia induces RAAS activation [33, 34, 35], and refraining from the euglycaemic clamp condition would have most likely exerted bias in renal function [19]. Insulin, on the other hand, is known to induce sodium retention, vasodilation and stimulation of sympathetic activity [36, 37, $38,39,40]$, which also could have influenced our results. However, the low dose of insulin that we used provides stable peripheral insulin concentrations of approximately $30 \mathrm{mU} / 1$ [20], i.e. slightly below the average insulin concentrations during daily life in diabetic patients. Therefore, our experimental conditions during the renal-function studies more or less mimic those in a well-regulated diabetic patient during daily life.

To avoid possible effects of long-term glycaemic status on RAAS-activity and RAAS-responsiveness, subjects with poor glycaemic control $\left(\mathrm{HbA}_{1 \mathrm{c}}>8.5\right)$ were excluded and consequently glycaemic control was satisfactory, as indicated by a mean $\mathrm{HbA}_{1 \mathrm{c}}$ of 7.3 and $7.5 \%$ in $I I$ - and $D D$-homozygotes, respectively. Despite this selection, $\mathrm{HbA}_{1 \mathrm{c}}$ was found to modify the overall responses to AngI and AngII of MAP, ERPF and RVR, which could be attributed to an effect on AngII responsiveness. This interaction was apparent during liberal sodium intake (Fig. 2) but did not reach statistical significance during low sodium intake. Whether this reflects a true biological interaction between glycaemic control and sodium status or less power during low sodium intake with smaller overall responses cannot be ascertained from our data. Nevertheless, these findings, obtained at pharmacological doses of angiotensin, raise the possibility that the haemodynamic consequences of a given concentration of AngII are modified by glycaemic status, which could have clinical implications. There is hardly any literature about the influence of long-term glycaemic control on pressor sensitivity. An increased renal haemodynamic response to ACE-inhibition in patients with a higher $\mathrm{HbA}_{1 \mathrm{c}}$ has been reported, indicating more pronounced RAAS activation [41]. Interactions between ACE-genotype and glycaemia-induced renal haemodynamic changes have been described. II-homozygotes were found to be resistant to glomerular changes induced by hyperglycaemia (preglomerular vasodilation), and II-carriers do not develop high glomerular capillary hydraulic pressure in response to hyperglycaemia, which has been suggested to provide a physiological basis for a reduced risk for nephropathy [42]. Recently, the deleterious effects of the $D D$-genotype were found to be most pronounced in people with poor glycaemic regulation [3]. To provide better evidence on interaction between prevalent glycaemic control and the effect of the ACE-genotype in diabetes, studies of different designs would be needed, studying a wider range of glycaemic control, and controlled studies comparing the effects of regimens of intensified versus conventional glycaemic control.

In our experimental set-up AngI responses were studied with AngII responses obtained during the same experiment as reference value, as AngII responsiveness is a main determinant of AngI responsiveness, also confirmed by our present data. This approach was chosen to avoid day-to-day differences between the AngI and AngII infusions. As the primary data were those on AngI response, the AngI infusion preceded the AngII infusion in fixed order, to avoid possible bias due to the preceding infusion. As a consequence, however, our data do not allow firm conclusions on AngII sensitivity as such-as recovery $2 \mathrm{~h}$ after AngI infusion was not always complete. However, as incomplete recovery was seen in both genotypes and we only used the AngII responses as an individual reference value, we consider our data to be valid for the multiple regression analysis.

In conclusion, in uncomplicated Type 1 diabetes mellitus the responses of blood pressure and renal haemodynamics to supraphysiological dosis of AngI are modulated by ACE-genotype and by sodium intake. The ultimate haemodynamic response to AngI, moreover, is also determined by the effects of long glycaemic control on AngII sensitivity. These data suggest that, under specific conditions, the ACE genotype could have functional consequences for RAASmediated (patho-) physiological responses.

Acknowledgements. This work was supported by grants from the Dutch Kidney Foundation (Grant C99.1861) and the Diabetes Research Fund (fellowship to Dr. K. Hoogenberg). We thank all patients who took part in this study. Furthermore, we gratefully acknowledge Mrs. A. Drenth-Bremer and Mrs. M. van Kammen for their technical assistance and Mr. J.H. Pol and Ms. A.K. van Zanten for their skilful determination of the renal haemodynamic parameters. Portions of this work were accepted for presentation at the annual meeting of the American Society of Nephrology, San Fransisco, November 2001, and were published in abstract form.

\section{References}

1. Fujisawa T, Ikegami H, Kawaguchi Y et al. (1998) Metaanalysis of association of insertion/deletion polymorphism of angiotensin I-converting enzyme gene with diabetic nephropathy and retinopathy. Diabetologia 41:47-53

2. Ha SK, Seo JK (1997) Insertion/deletion polymorphism in ACE gene as a predictor for progression of diabetic nephropathy. Kidney Int Suppl 60:S28-S32

3. Hadjadj S, Belloum R, Bouhanick B et al. (2001) Prognostic value of angiotensin-I converting enzyme I/D polymorphism for nephropathy in type 1 diabetes mellitus: a prospective study. J Am Soc Nephrol 12:541-549

4. Penno G, Chaturvedi N, Talmud PJ et al. (1998) Effect of angiotensin-converting enzyme (ACE) gene polymorphism on progression of renal disease and the influence of ACE inhibition in IDDM patients: findings from the EU- 
CLID Randomized Controlled Trial. EURODIAB Controlled Trial of Lisinopril in IDDM. Diabetes 47:15071511

5. Jacobsen P, Rossing K, Rossing P et al. (1998) Angiotensin converting enzyme gene polymorphism and ACE inhibition in diabetic nephropathy. Kidney Int 53:1002-1006

6. Perna A, Ruggenenti P, Testa A et al. (2000) ACE genotype and ACE inhibitors induced renoprotection in chronic proteinuric nephropathies1. Kidney Int 57:274-281

7. Kleij FG van der, Schmidt A, Navis GJ et al. (1997) Angiotensin converting enzyme insertion/deletion polymorphism and short- term renal response to ACE inhibition: role of sodium status. Kidney Int Suppl 63:S23-S26

8. Rigat B, Hubert C, Alhenc-Gelas F, Cambien F, Corvol P, Soubrier F (1990) An insertion/deletion polymorphism in the angiotensin I-converting enzyme gene accounting for half the variance of serum enzyme levels. J Clin Invest 86:1343-1346

9. Mizuiri S, Hemmi H, Kumanomidou H et al. (2001) Angiotensin-converting enzyme (ACE) I/D genotype and renal ACE gene expression. Kidney Int 60:1124-1130

10. Danser AH, Koning MM, Admiraal PJ et al. (1992) Production of angiotensins I and II at tissue sites in intact pigs. Am J Physiol 263:H429-H437

11. Costerousse O, Allegrini J, Lopez M, Alhenc-Gelas F (1993) Angiotensin I-converting enzyme in human circulating mononuclear cells: genetic polymorphism of expression in T-lymphocytes. Biochem J 290 (Pt 1):33-40

12. van der Kleij FG, de Jong PE, Henning RH, de Zeeuw D, Navis G (2002) Enhanced responses of blood pressure, renal function, and aldosterone to angiotensin I in the DD genotype are blunted by low sodium intake. J Am Soc Nephrol 13:1025-1033

13. Ueda S, Elliott HL, Morton JJ, Connell JM (1995) Enhanced pressor response to angiotensin I in normotensive men with the deletion genotype (DD) for angiotensin-converting enzyme. Hypertension 25:1266-1269

14. Lieberman J, Sastre A (1980) Serum angiotensin-converting enzyme: elevations in diabetes mellitus. Ann Intern Med 93:825-826

15. Van Dyk DJ, Erman A, Erman T, Chen-Gal B, Sulkes J, Boner G (1994) Increased serum angiotensin converting enzyme activity in type I insulin-dependent diabetes mellitus: its relation to metabolic control and diabetic complications [published erratum appears in Eur J Clin Invest 1994 Oct;24(10):711]. Eur J Clin Invest 24:463-467

16. Rogacz S, Williams GH, Hollenberg NK (1990) Time course of enhanced adrenal responsiveness to angiotensin on a low salt diet. Hypertension 15:376-380

17. Volpe M, Muller FB, Trimarco B (1985) Transient enhancement of sympathetic nervous system activity by longterm restriction of sodium intake. Circulation 72:47-52

18. Dullaart RP, Meijer S, Sluiter WJ, Doorenbos H (1990) Renal haemodynamic changes in response to moderate hyperglycaemia in type 1 (insulin-dependent) diabetes mellitus. Eur J Clin Invest 20:208-213

19. Osei SY, Price DA, Fisher ND, Porter L, Laffel LM, Hollenberg NK (1999) Hyperglycemia and angiotensinmediated control of the renal circulation in healthy humans. Hypertension 33:559-564

20. Hoogenberg K, Sluiter WJ, Navis G et al. (1998) Exogenous norepinephrine induces an enhanced microproteinuric response in microalbuminuric insulin-dependent diabetes mellitus. J Am Soc Nephrol 9:643-654

21. Apperloo AJ, Zeeuw D de, Donker AJ, Jong PE de (1996) Precision of glomerular filtration rate determinations for long-term slope calculations is improved by simultaneous infusion of 125I-iothalamate and 131I-hippuran. J Am Soc Nephrol 7:567-572

22. Kwarts E, Beukenveld G, Gazendam J (1982) Evaluation of a simple colorimetric assay for serum angiotensin-converting enzyme: comparison with a new ion-pair liquid chromatography-assisted assay. Ann Clin Biochem $19(\mathrm{Pt}$ 4):227-232

23. Chadwick IG, O'Toole L, Morice AH, Yeo WW, Jackson PR, Ramsay LE (1997) Pressor and hormonal responses to angiotensin I infusion in healthy subjects of different angiotensin-converting enzyme genotypes. J Cardiovasc Pharmacol 29:485-489

24. Lachurie ML, Azizi M, Guyene TT, Alhenc-Gelas F, Menard J (1995) Angiotensin-converting enzyme gene polymorphism has no influence on the circulating renin-angiotensin-aldosterone system or blood pressure in normotensive subjects. Circulation 91:2933-2942

25. Shoback DM, Williams GH, Hollenberg NK, Davies RO, Moore TJ, Dluhy RG (1983) Endogenous angiotensin II as a determinant of sodium-modulated changes in tissue responsiveness to angiotensin II in normal man. J Clin Endocrinol Metab 57:764-770

26. Sharma AM, Schattenfroh S, Thiede HM, Oelkers W, Distler A (1992) Effects of sodium salts on pressor reactivity in salt-sensitive men. Hypertension 19:541-548

27. Hollenberg NK, Chenitz WR, Adams DF, Williams GH (1974) Reciprocal influence of salt intake on adrenal glomerulosa and renal vascular responses to angiotensin II in normal man. J Clin Invest 54:34-42

28. Boddi M, Poggesi L, Coppo M et al. (1998) Human vascular renin-angiotensin system and its functional changes in relation to different sodium intakes. Hypertension 31:836-842

29. Miller JA, Scholey JW, Thai K, Pei YP (1997) Angiotensin converting enzyme gene polymorphism and renal hemodynamic function in early diabetes. Kidney Int 51:119-124

30. Fukumoto S, Ishimura E, Hosoi M et al. (1996) Angiotensin converting enzyme gene polymorphism and renal artery resistance in patients with insulin dependent diabetes mellitus. Life Sci 59:629-637

31. Mogensen CE, Christensen CK (1984) Predicting diabetic nephropathy in insulin-dependent patients. N Engl J Med 311:89-93

32. Rudberg S, Persson B, Dahlquist G (1992) Increased glomerular filtration rate as a predictor of diabetic nephropathy-an 8-year prospective study. Kidney Int 41:822-828

33. Miller JA (1999) Impact of hyperglycemia on the renin angiotensin system in early human type 1 diabetes mellitus. J Am Soc Nephrol 10:1778-1785

34. Lansang MC, Osei SY, Coletti C, Krupinski J, Hollenberg NK (2002) Hyperglycaemia-induced intrarenal RAS activation: the contribution of metabolic pathways. J Renin Angiotensin Aldosterone Syst 3:19-23

35. Osei SY, Price DA, Laffel LM, Lansang MC, Hollenberg NK (2000) Effect of angiotensin II antagonist eprosartan on hyperglycemia-induced activation of intrarenal renin-angiotensin system in healthy humans. Hypertension 36:122-126

36. DeFronzo RA, Cooke CR, Andres R, Faloona GR, Davis PJ (1975) The effect of insulin on renal handling of sodium, potassium, calcium, and phosphate in man. J Clin Invest 55:845-855

37. Steinberg HO, Brechtel G, Johnson A, Fineberg N, Baron AD (1994) Insulin-mediated skeletal muscle vasodilation is nitric oxide dependent. A novel action of insulin to increase nitric oxide release. J Clin Invest 94:1172-1179

38. Scherrer U, Randin D, Vollenweider P, Vollenweider L, Nicod P (1994) Nitric oxide release accounts for insulin's vascular effects in humans. J Clin Invest 94:2511-2515 
P. T. Luik et al.: The influence of the ACE (I/D) polymorphism on systemic and renal vascular responses

39. Anderson EA, Hoffman RP, Balon TW, Sinkey CA, Mark AL (1991) Hyperinsulinemia produces both sympathetic neural activation and vasodilation in normal humans. J Clin Invest 87:2246-2252

40. Gans RO, Bilo HJ, Nauta JJ, Heine RJ, Donker AJ (1992) Acute hyperinsulinemia induces sodium retention and a blood pressure decline in diabetes mellitus. Hypertension 20:199-209
41. Jenkins DA, Cowan P, Collier A, Watson ML, Clarke BF (1990) Blood glucose control determines the renal haemodynamic response to angiotensin converting enzyme inhibition in type 1 diabetes. Diabet Med 7:252-257

42. Marre M, Bouhanick B, Berrut G et al. (1999) Renal changes on hyperglycemia and angiotensin-converting enzyme in type 1 diabetes. Hypertension 33:775-780 